\title{
Assessing the Sustainable Development through Physical Infrastructure Sustainability: Water Pollution and Environmental Degradation at Ritual Tank Ambala, Ramtek
}

\author{
Kalpana N. Kawathekar (Thakare) ${ }^{1}$, A. J. Sanyal ${ }^{2}$ \\ ${ }^{1}$ Research Scholar, Rashtrasant Tukadoji Maharaj Nagpur University, Nagpur), Associate Professor, Dept. of Arch, K.I.T.S., Ramtek, \\ Nagpur \\ ${ }^{2}$ Professor, Supervisor, Former Principal and Presently Professor, Design Chair, M.I.E.T., Gondia
}

\begin{abstract}
Ambala, the 'Kashi/ Ganga of South' of Vidarbha in Ramtek has its regional importance for want of pilgrimmage, sociocultural, heritage and Eco-tourism. The Ambala Water Tank was made by King 'Amba' for having got his skin disease cured by washing the face and hands by its water. The groups of temples were constructed along edges of the Ambala tank by the Bhosla Kings of Nagpur who had their week end retreat and religious centre at Ramtek. The geographical setting shows the Ambala valley collecting the rain water from all around hills making the water medically pure for drinking purpose. Today, Ambala tank water is used for the Ganesh/Goddess idol Visarjan, temple rituals, cremation, Asthivisarjan Puja/ Dashakriya rituals, bathing, fishing, washing clothes etc. The overflow drains, few drain outlets from Ambala settlement are also passed into the water tank. The water body is getting polluted due to all these activities day by day. The urban local body (ULB) is responsible for the maintenance of the area. It is using customary ways of maintenance which are observed in effective as the stagnant water is getting smelly and polluted due to waste thrown in to the water by means of different activities. Public Private Participation is one solution identified with the strategic plan to involve the ULB, Local public and the NGO's for conservation management of Water from Ambala tank. Strategic planning for the conservation of Ambala tank water is discussed in this paper by the authors.
\end{abstract}

Keywords: Drainage and Waste disposal, Water pollution, Environment Degradation, Water Infrastructure Conservation and Management, Sustainable Development

\section{Ambala, Ramtek ; A Ritual Centre In Vidarbha}

\subsection{Significance of Ambala}

Ambala, re-knowned as 'Kashi/ Ganga of South' from Vidarbha, has its regional importance for want of pilgrimmage, socio-cultural heritage and Eco-tourism. This area is very much famous for its natural beauty due to availability of flora and fauna in the reserved forest. The geographical setting shows the Ambala valley collecting the rain water from all around hills making the water medically pure for drinking purpose. The area observes the collection of rain water in the valley between the hills all around. The water flowing through the hills surrounding Ambala gives medicinal effects due to existence of ayurvedic plants on these hills.

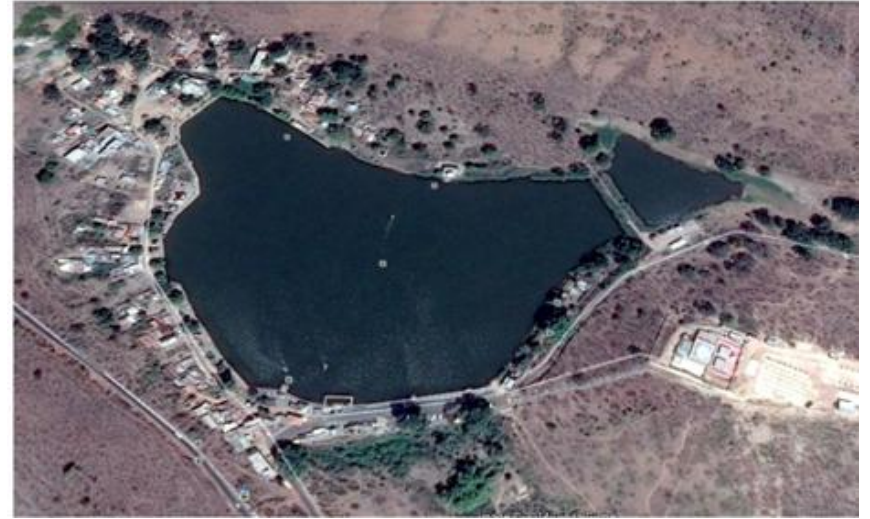

Figure 1: Image of Ambala Water Tank, Ambala, Ramtek (Source: www.googleearth.com, image collected on dtd September 15, 2014)

\subsection{Historical Importance of Ambala}

- The Ambala Water Tank was made by the King 'Amba' for having got his skin disease cured by washing the face and hands by this water.

- Due to its purity and medical quality the Ambala Lake water is used for holy Bath, asthivisarjan/ dasakriya pujan etc. which gives the same feeling as that of holy water of the river Ganga.

- The pilgrims visiting Rammandir at the top of the Ramgiri hill on the west of Ambala used to use the route via Ambala Lake and the steps from Ambala to Gad mandir precinct (Ram Temple). 


\section{International Journal of Science and Research (IJSR) \\ ISSN (Online): 2319-7064}

Index Copernicus Value (2013): 6.14 | Impact Factor (2015): 6.391

- The groups of temples facing east, across the water body were constructed along the Ambala tank by the Bhosla Kings of Nagpur before three centuries from now who had their week end retreat and religious centre at Ramtek.

\subsection{Location, Geography \& Area}

Ambala is a part of Ramtek. It is having Ambagad mountain range tracts in the west side of Ramtek. Ramtek is a small town ( $\mathrm{C}$ category) and a sub district centre under Nagpur District on its Northeast of Vidarbha region of Maharashtra state from India. It is bounded by Madhya Pradesh state on its Northern side, and Bhandara district on eastern side. It is connected with the other areas of Nagpur District through the boundary of Maharashtra state. The national highway No. 7 Nagpur Jabalpur Highway passes through this area. The state highway no. 249 (Mansar - Tumsar) passing through the Ramtek town joins this national highway on the western side end. The Sur river and Kapila River flow through the region. Various Natural and artificial lakes span the length and breadth of the region. Latitude $21^{0} 21^{\prime} 52.88^{\prime \prime} \mathrm{N}$ and longitude $79^{0} 20^{\prime} 24.48^{\prime \prime}$ E of Ramtek Ambala.

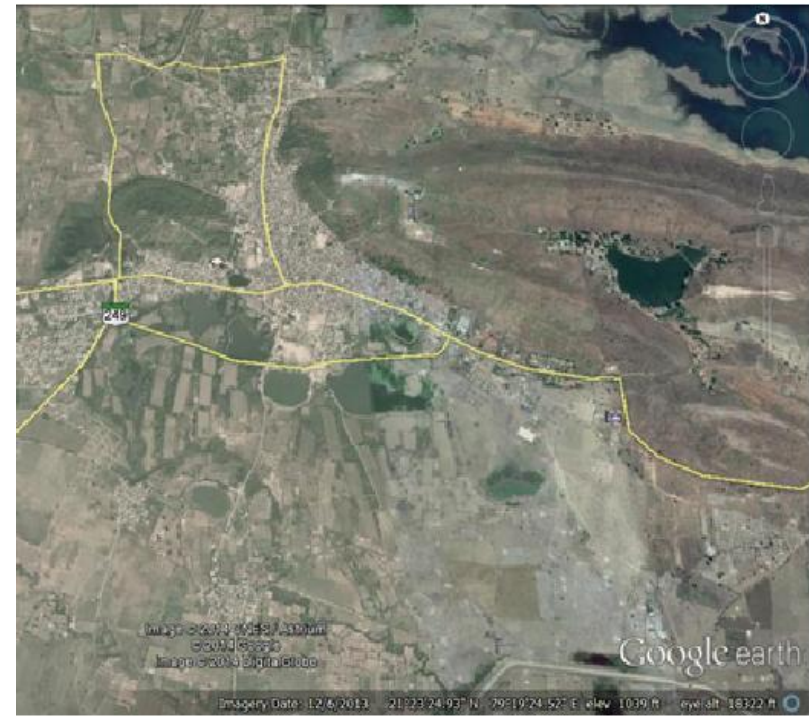

Figure 2: Google imagery of Ramtek showing 1. Ambala with its surrounding 2. hills and 3. Ramtek town settlement (Source: www.googleearth.com, image collected on dated June 12, 2013)

\section{Usage of Water Tank}

Today, Ambala tank water is used for the Ganesh/ Goddess idol Visarjan, temple rituals, Ganga pujan, ritual baths cremation, Asthivisarjan Puja/ Dashakriya rituals in addition to using it for the daily activities like fishing, bathing, washing clothes etc. The overflow drains and few drain outlets from Ambala settlement are also passed into the water tank. The water body is getting polluted due to all these activities day by day.

Ramtek Nagar Parishad, the urban local body (ULB) is responsible for the maintenance of the area. It is using customary ways of maintenance which are observed ineffective as the stagnant water is getting smelly and polluted due to waste thrown in to the water by means of different activities sighted earlier.

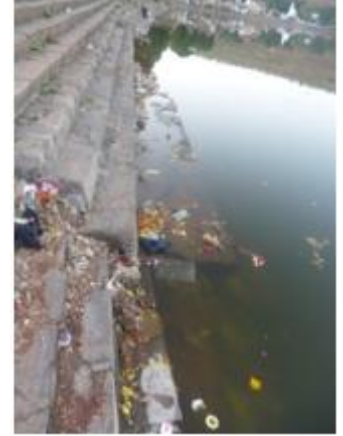

Figure 3: Wastage put in to the Ambala tank water (Photo

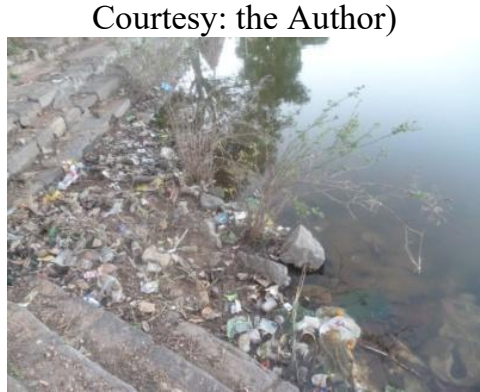

Figure 4: Waste put in to the Ambala tank water (Photo Courtesy: the Author)

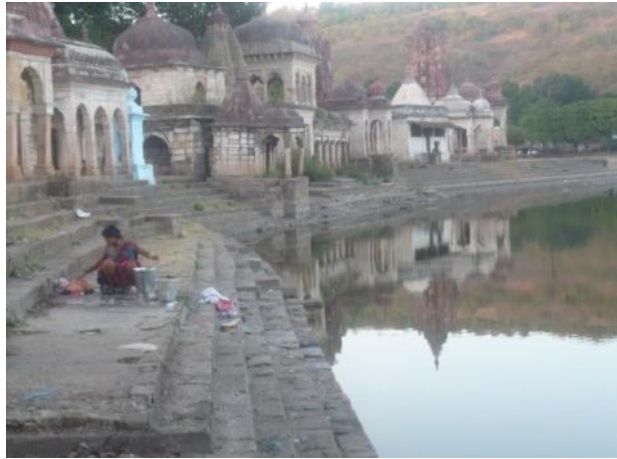

(5)

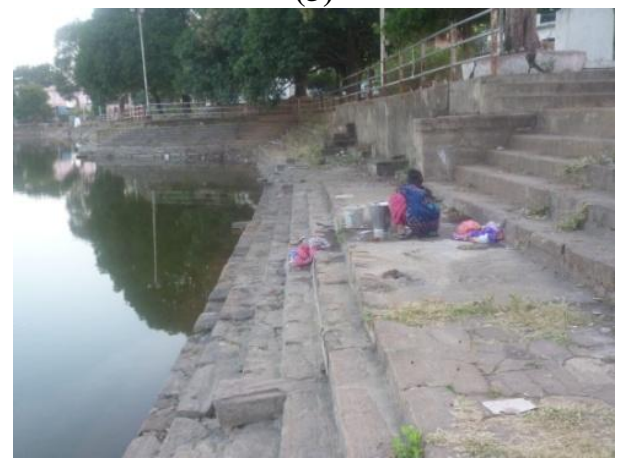

(6)

Figure 5 \& 6: Daily cloth washing activities by the public from neighboring areas at Ambala water tank (Photo Courtesy: the Author) 
International Journal of Science and Research (IJSR)

ISSN (Online): 2319-7064

Index Copernicus Value (2013): 6.14 | Impact Factor (2015): 6.391

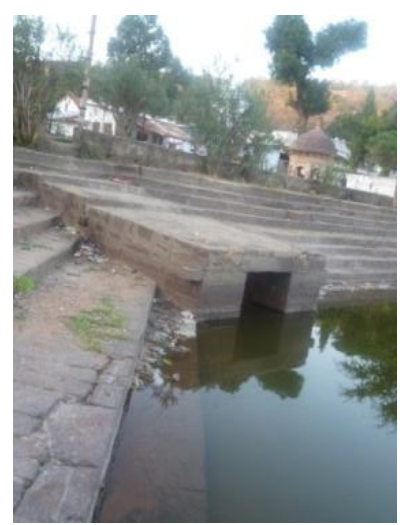

(7)

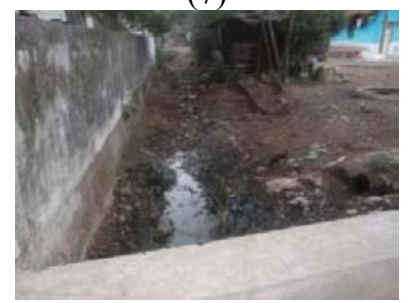

(8)

Figure 7 and 8: Drains from neighboring areas connecting to the Ambala tank water (Photo Courtesy: the Author)

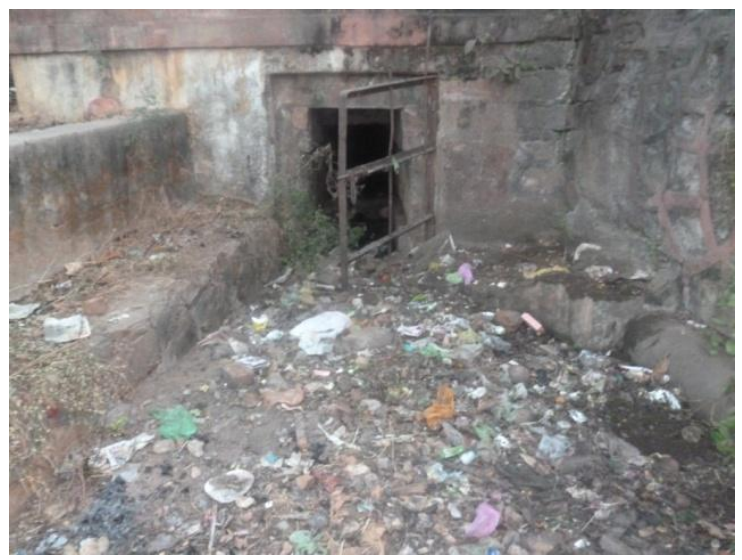

Figure 9: Solid Waste thrown into the drains leading to Ambala tank (Photo Courtesy: the Author)

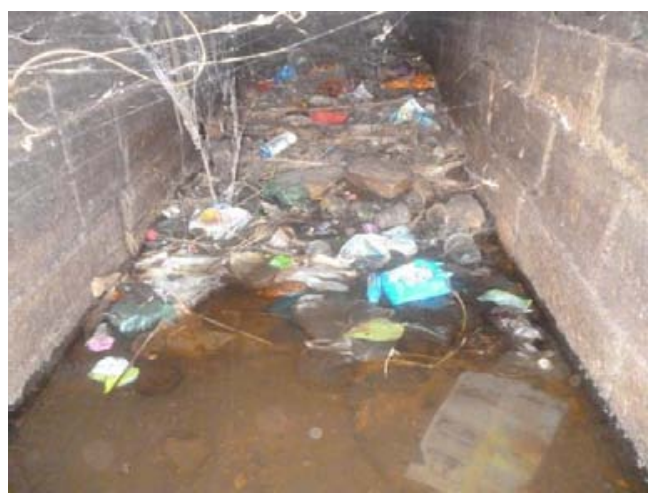

Figure 9: Solid Waste along with the plastic bags thrown into the drains leading to Ambala tank (Photo Courtesy: the Author)

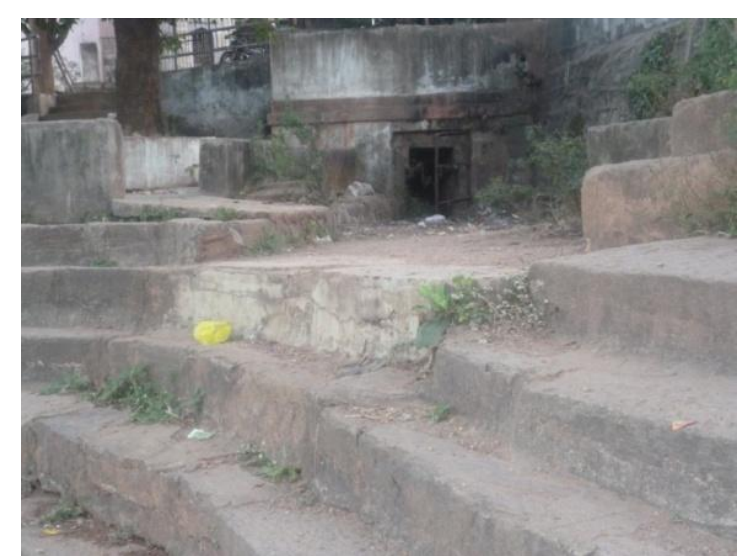

Figure 10: Drains opening into the Ambala tank (Photo Courtesy: the Author)

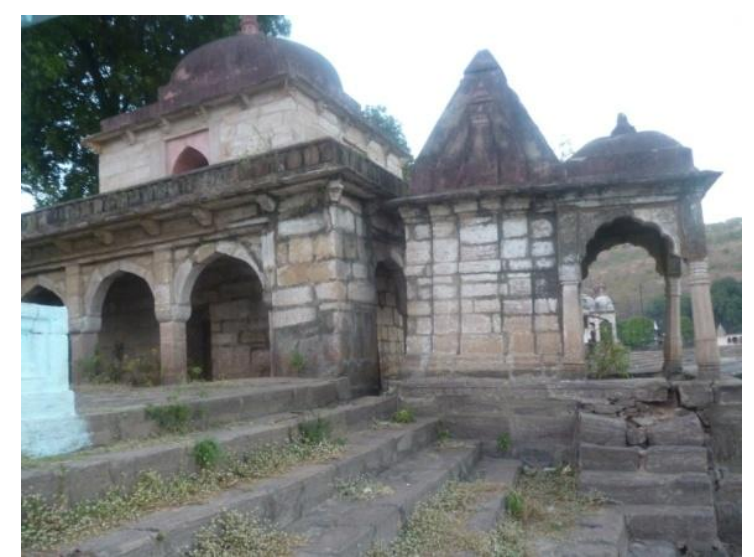

(12)

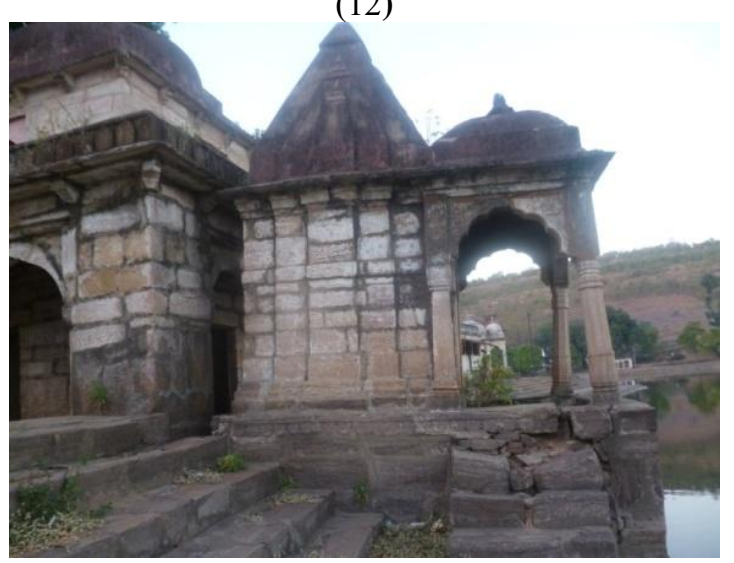

(13)

Figure 12 and 13: Built heritage getting damaged at Ambala tank water (Photo Courtesy: the Author)

\section{Issues Associated To Activities In And Outside Ambala Tank}

Volume 5 Issue 7, July 2016 www.ijsr.net 
International Journal of Science and Research (IJSR)

ISSN (Online): 2319-7064

Index Copernicus Value (2013): 6.14 | Impact Factor (2015): 6.391

\begin{tabular}{|c|c|c|}
\hline $\begin{array}{c}S r . \\
\text { No. }\end{array}$ & Activity & Issues \\
\hline 1 & $\begin{array}{l}\text { Puja: Temple } \\
\text { Rituals in the } \\
\text { shiva temples, } \\
\text { Sun temple etc. } \\
\text { round the year }\end{array}$ & $\begin{array}{c}\text { Emersion of used material/ waste (non } \\
\text { degredable) in water, } \\
\text { Throwing of papers \& plastics in to water } \\
\text { body. } \\
\text { Temples are not maintained. }\end{array}$ \\
\hline 2 & Cremation & $\begin{array}{l}\text { Direct throw of ashes } \\
\text { Other wastes including non degradables } \\
\text { thrown in to the water body } \\
\text { Water being stagnant recharging process } \\
\text { takes longer time. }\end{array}$ \\
\hline 3 & Ritual bathing & $\begin{array}{c}\text { The saloon venders use the steps of the tank } \\
\text { for cutting of hairs and allow the garbage to } \\
\text { get into the water body along with the } \\
\text { surrounding waste. } \\
\text { Gender wise separate changing rooms and } \\
\text { bathrooms are not provided in adequate } \\
\text { number as well as in terms of neat and } \\
\text { cleanliness. }\end{array}$ \\
\hline 4 & Fishing & $\begin{array}{l}\text { Due to fishing activity it helps to maintain the } \\
\text { water body inside but visitors throw in the } \\
\text { eatables for attracting the fishes thus littering. } \\
\text { Sometimes the eatables are harming the } \\
\text { aquatic life. }\end{array}$ \\
\hline 5 & Other & $\begin{array}{l}\text { The number of street venders come to sale } \\
\text { the commodity and throws away the waste } \\
\text { during working hours. } \\
\text { Routine activities of ambala population } \\
\text { allowing chemicals and pollutants in to water } \\
\text { body through bathing, washing clothes and } \\
\text { cattle etc.. } \\
\text { Drainage being open it allows rain water } \\
\text { drain to take away drains from houses into } \\
\text { ambala water tank. } \\
\text { Seepage of water from the drains and septic } \\
\text { tanks into ambala }\end{array}$ \\
\hline
\end{tabular}

\section{Need For Environment Conservation and Management}

The issues identified above gives us the inferences as to work for conservaton of water at ambala:

a) To allow the water movement,

b) To restrict the eatables/ waste/ pollutants thrown into water tank,

c) To stop collection of wastes from doorstep into water body,

d) To stop leakages from septic tanks,

e) To maintain cleanliness of temples,

f) To maintain the Temple structures,

g) To reduce the desilting of soil.

After looking at the above, the three major areas are observed as of prime concern which needs to be looked after and which can also bring up the secondary needs.

The primary concerns include the following for the Conservation Management.

a) The water quantity and quality

b) Forest cover conservation

c) Conservation of Terrain

\section{Possible Solutions}

The possible solutions for conservation management of the primary concerns viz. water quantity and quality, Forest cover conservation and Conservation of Terrain are as follows:

a) Awareness of the local public

b) ULB involvement for conservation of ambala

c) Public Private Participation

Awareness of the local public can be achieved through various street plays, presentations and actual involvement by NGO's in routine activity awareness making. By involving the local public and showing the benefit of the activities to locals as well as tourists and pilgrims through a step forward Public Private Participation can work out successfully. Ramtek Nager Parishad, who is already into the maintenance activity should plan for the long run sustainability of the culture and heritage.

\section{Strategic Plan For Conservation Management}

Strategic Plan for Conservation Management will include the following with the active participation of local members:

1) Planning Strategy: Planning of Activities on the priority basis.

2) Implementation strategy: Administering the implementation of plans for conservation

3) Evaluation strategy: Survey and analysis method to keep a check over the planning and implementation.

To work on the strategic plan for conservation management of Water from Ambala tank Public Private Participation is the best solution to involve the ULB, Local public and the NGO's

\section{References}

[1] Report on 'Development Plan of Ramtek' by Nagar Parishad, Ramtek, 1993 -2013,

[2] Maharashtra State Government of India, 'Nagpur District Gazetteer Part I \& II', Revised Edition 2005.

[3] Maharashtra State Government of India, Nagpur District Statistical Report, 2011.

[4] www.googleearth.com/ramtek

[5] www.censusofIndia2011/district/population

\section{Author Profile}

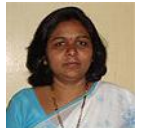

Ms. Kalpana N. Kawathekar (Thakare) is an Architect and Planner from IIT Roorkee and is pursuing Research in Architecture and Planning under faculty of Engg. \& Technology at R.T.M.N.U., Nagpur. Formerly she was The Head, Dept. of Arch, K.I.T.S., Ramtek and now doing as Associate Professor at K.I.T.S., Ramtek.

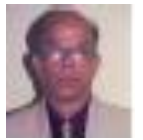

Prof. A. J. Sanyal is an Architect and Planner from Nagpur Region. Sir is an academician with expertise in spectrum of subjects.. He was formerly the Principal and presently doing as Professor, Design Chair at M..I.E.T., Gondia 